\title{
Evaluation of Sources and Options for Possible Clean up of Anthropogenic Mercury Contamination in the Ankobra River Basin in South Western Ghana
}

\author{
Thomas Mba Akabzaa, Sandow Mark Yidana*
}

Department of Earth Science, University of Ghana, Legon, Ghana.

E-mail: *smyidana@ug.edu.gh, *yidanas117@gmail.com

Received October $9^{\text {th }}$, 2011; revised November $11^{\text {th }}$, 2011; accepted December $4^{\text {th }}, 2011$.

\begin{abstract}
The study assesses the spatial distribution and sources of mercury contamination in the Ankobra River Basin in southwestern Ghana and discusses possible remediation options and challenges. Eighty-two (82) samples of water and streambed sediments from areas of active and historic artisanal mining and historic mine spoil from large-scale mining were analysed for their total mercury content using cold vapour Atomic Fluorescence Spectrometry (CV-AAS). The highest $\mathrm{Hg}$ concentrations were recorded from historic mine tailings, legacy of large scale mines in the area, which averaged $795 \mathrm{ppb}$ but ranged from $80 \mathrm{ppb}$ to $2500 \mathrm{ppb}$. Concentrations in streambed sediments averaged $139 \mathrm{ppb}$, but ranged from $63 \mathrm{ppb}$ to $270 \mathrm{ppb}$. Water, expectedly, gave the lowest $\mathrm{Hg}$ concentrations with a mean value of $1.5 \mathrm{ppb}$, but ranged from below detection to $8 \mathrm{ppb}$. Areas worked by artisanal miners and historic tailings dumps at Bondaye and Prestea recorded the highest mercury values. These high mercury concentration sites constitute potential sources of major mercury pollution in the area and therefore require major and urgent clean up to mitigate any major health risks. However, any remediation strategy would require further and detailed study of the contaminated sites and an evaluation of known remediation techniques to achieve maximum results.
\end{abstract}

Keywords: Ankobra Basin, Mercury Contamination, Clean-Up, Old Tailings, Sediments, Water

\section{Introduction}

Mercury pollution is a very serious environmental problem because elevated concentrations are toxic to living organisms with the degree of toxicity varying with its chemical form. Organic mercury, particularly methyl mercury is said to be more than 1000 times as toxic as elemental mercury. The effects of mercury on humans are well documented. It causes damages to the central nervous system and is especially toxic to the foetus $[1,2]$.

Mercury in the environment comes from both natural and anthropogenic sources. Naturally, cinnabar (HgS) is practically the only source of the metal, while the most important anthropogenic sources of mercury pollution are from the mining industry [3].

Commercial deposits of cinnabar have not be reported in Ghana, although stream channel sampling have revealed a promising mercury dispersion zone in the valley of Tromia in Brong Ahafo region of the country [4]. On the whole, no significant natural sources of the metal are known in Ghana as efforts at other areas in the country have so far not indicated mercury concentrations significantly above its crustal abundance of $30 \mathrm{ppb}$. However, studies in traditional mining centres in Ghana such as Obuasi and Tarkwa have reported elevated mercury levels in stream water, sediments, fish, and plants [5,6]. Most of these studies assigned the activities of artisanal miners, who use mercury for gold recovery, as the primary source of mercury dispersion in Ghana. The present study area has over 500 years of artisanal activities. Apart from these artisanal miners, mercury was pervasively used in largescale mining in Ghana until the early 1990s when it was officially prohibited in large-scale mining. During that period, over 15 large-scale gold mines in the Tarkwa mining district, many of them abandoned today, used mercury for gold recovery. The area has seen over 100 years of large-scale gold mining [7]. These mines left on their 
trail scattered mercury-laced tailing dumps. For instance, over hundred years of gold extraction using mercury in the three underground mines at Prestea, Tuapim and Bondaye, about $65 \mathrm{~km}$ from Tarkwa, has generated three vast expanse of tailings dumps, covering a total area of about $30 \mathrm{~km}^{2}$, while similar operations at the Tarkwa underground mine has also generated tailings covering over 16 $\mathrm{km}^{2}$ of land space.

Studies have shown that the Ankobra River Basin, which takes drainage from these mining anthropogenic activities, and is indeed itself being mined by both legal and illegal artisanal miners, has poor abundance of fish and invertebrates because of heavy metal pollution. Other studies have reported widespread augmented mercury levels in food crops such as cassava, cocoyam and in fish in the area [6].

There has not been any systematic study to assess the extent of Hg contamination in the area. In fact, the impacts and extent of mercury pollution in Ghana are not yet understood. This exploratory data clearly shows that the need to clean up mercury in the area is a delayed priority. This paper, which explores the problem of mercury pollution in the Ankobra River Basin and its mosaic of tributaries, has provided data that justifies the urgent call for the clean up of the contaminated sites. Various clean up options have been discussed.

\section{The Study Area}

The study area is in the Wassa West District of the Western Region of Ghana (Figure 1), and is a major mining hub in Ghana, defined by several major mining towns such as Nsuta, Tarkwa, Damang, Abosso, Bogoso, and Prestea. The area is one of the few remaining corridors of Ghana's tropical rain forest that is fast depleting by human activity, including mining. Annual rainfall data for the area indicate minimum and maximum values of 1449 $\mathrm{mm}$ and $2608 \mathrm{~mm}$ respectively, while annual temperatures range from $25^{\circ} \mathrm{C}$ to $29^{\circ} \mathrm{C}$ [8].

The Ankobra River and its mosaic of tributaries (Figure 2) receive various mine-impacted water from largescale gold mines at Prestea, Bogoso, Tarkwa and Damang, as well as small-scale, often illegal mining operations, within the area.

The gold occurs in lenses of sulphide-bearing quartz veins, mainly in carbonaceous phyllite, as disseminated sulphides in the metavolcanics, or as oxidised derivatives of the two types in the Birimian rocks and in conglomeritic horizons as free milling gold in the Tarkwaian. It is the oxidised ores and the free milling varieties that are most amenable to dressing with mercury.

\section{Materials and Methods}

A total of 70 water samples from streams, boreholes, and hand dug wells; 6 samples each of stream sediment from channel-bed alluvium and material from old tailings dumps, respectively, were collected and their locations noted with a Global Positioning System (GPS) and recorded on a sample location map (Figure 2). Sample collection, preservation, storage, preparation and quality control/quality assurance (QC/QA) protocols followed those outlined by

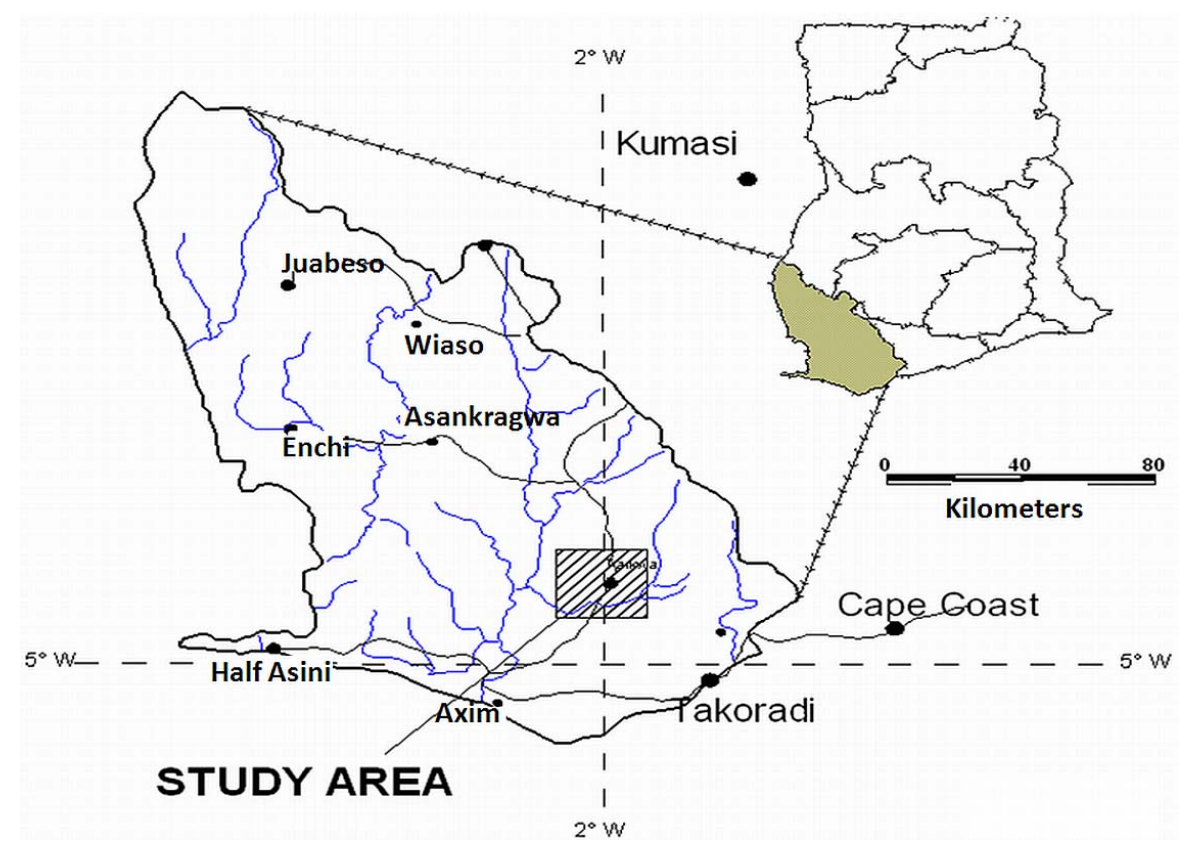

Figure 1. A map of Ghana showing the study area. 


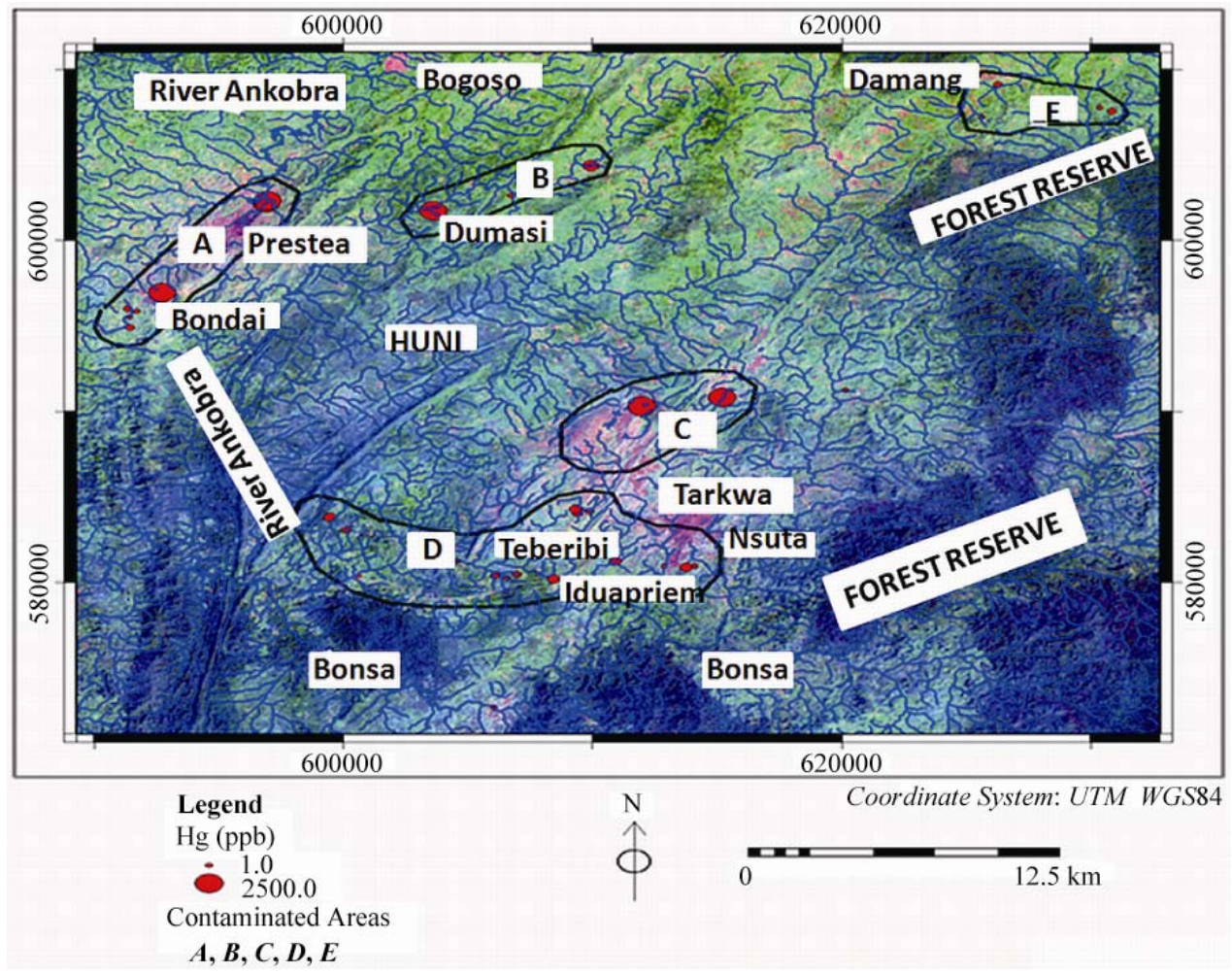

Figure 2. Mercury contaminated sites identified for possible clean-up planning.

Eppinger et al. [9], APHA [10], Bloom and Fitzgerald [11] and Barcelona et al. [12]. Water samples were acidified with pure nitric acid $\left(\mathrm{HNO}_{3}\right)$ to $\mathrm{pH}$ less than 2 to prevent possible reaction of the dissolved species [13] and total mercury determined by cold vapour Atomic Fluorescence Spectrometry (CV-AAS) and expressed in parts per billion (ppb) with detection limit of $1 \mathrm{ppb}$.

Plastic scoop was used to sample stream sediments and tailings material into polyethylene sampling bags and tightly secured. The samples were oven-dried at $40^{\circ} \mathrm{C}$ and sieved to 80 meshes. Total nitric acid extraction was then applied to this fraction to obtain a leachate, which was then analysed for $\mathrm{Hg}$ using the same cold vapour Atomic Fluorescence Spectrometry.

Analyses were performed at the Water Research Institute (WRI) of the Council for Scientific Research (CSIR), with duplicates of select samples analysed at the SGS Commercial laboratory and the Ecological Laboratory (Ecolab) of the University of Ghana for quality assurance and con- trol purposes.

\section{Results}

The results of mercury concentrations in the various media are presented as summarised descriptive statistics in Table 1. The concentration of total mercury in stream sediments and mine tailings are presented in Tables 2 and 3 , respectively. The samples exhibit variable total Hg mercury concentrations ranging from $33 \mathrm{ppb}-25,000 \mathrm{ppb}$ in old mine tailing dumps, $63 \mathrm{ppb}$ to $270 \mathrm{pbb}$ in streambed sediments and from $<1 \mathrm{ppb}$ to $8 \mathrm{ppb}$ for water samples (Table 1).

\subsection{Hg in Mine Tailings and Streambed Sediments}

Mine tailings and stream sediments have mercury concentrations of over 10 - 100 fold the levels in water. The highest $\mathrm{Hg}$ concentrations were recorded from historic mine tailings with average concentration of 795 pbb.

Table 1. Summary descriptive statistics of $\mathbf{H g}$ concentrations in various media in ppb.

\begin{tabular}{|c|c|c|c|c|c|c|}
\hline Sampling Media & Mean & Median & Standard Deviation & Minimum & Maximum & Count \\
\hline Water & 1.5 & 1 & 1.25 & $<1$ & 8 & 70 \\
\hline Streambed sediments & 139 & 100 & 87.65 & 63 & 270 & 6 \\
\hline Old Mine Tailing Dumps & 795 & 72 & 1154.67 & 33 & 2500 & 6 \\
\hline
\end{tabular}


Table 2. Concentration of mercury in various mine spoil and stream sediments.

\begin{tabular}{clc}
\hline Sample & \multicolumn{1}{c}{ Old mine tailing dumps } & Hg (ppb) \\
\hline & & \\
PGRTD01 & Old Tailings at Prestea, now being mined by PSGL & 2500 \\
SSPGRB01 & Sediments from stream taking seepage from tailings at Bondaye & 97 \\
SSGFL01 & Soil from rehabilitated waste rock site & 43 \\
TSGFL01 & Tailings from abandoned underground mine & 80 \\
PGRTD02 & Old tailings being re-mined by Bondaye & 2050 \\
TSGFL04 & Ancient tailings from Tarkwa underground mine & 33 \\
& & \multicolumn{1}{c}{ Streambed Sediments } \\
SSA01 & Sediments from the Ankobra river at point where drainage from PSGL Operations enter it & 230 \\
TSPGRB01 & Sediments from stream draining old tailings at Bondaye & 270 \\
GMCTS01 & Stream sediments from the Kawere stream near Nsuta & 103 \\
SSPGRB03 & Stream draining ancient tailings dump near Bondaye & 63 \\
SS1 & Stream sediments from Bonsa Stream & 63 \\
SSTGL-6 & Stream sediments from Bedibewuo stream near Tarkwa & 70 \\
\hline
\end{tabular}

Material taken from tailings dumps in Bondaye and Prestea underground mines gave the highest mercury values of $2025 \mathrm{ppb}$ and $2500 \mathrm{ppb}$ respectively (Table 2) and area A in Figure 2.

Mercury levels in stream sediments are generally lower than those from the tailings dumps. The highest $\mathrm{Hg}$ values of $270 \mathrm{ppb}$ and $230 \mathrm{ppb}$ were obtained from stream sediments samples taken from a tributary of the Ankobra draining the old tailing dump at Bondaye and the Ankobra River itself respectively. Augmented mercury concentrations ranging from $63 \mathrm{ppb}$ to $103 \mathrm{ppb}$ were obtained from sediment samples at the Bonsa River, Bedibewuo stream, and the Kawere, where active artisanal mining activities are brisk (Table 2).

\subsection{Water Samples}

Water samples showed the lowest mercury concentrations among the three media sampled, and ranged generally from below detection to $8 \mathrm{ppb}$, with high concentrations coincident with areas of small-scale mining activity, such as streams in the Bogoso area, including the Ankobra River. All samples from streams with artisanal mining activities gave $\mathrm{Hg}$ concentrations of at least $1 \mathrm{ppb}$. High mercury values were also observed from water from streams that drain the old tailings dumps at Prestea and Tarkwa, with the highest value of $8 \mathrm{ppb}$ recorded in a stream that takes drainage from the Bondaye old tailings dump which gave the very high $\mathrm{Hg}$ concentration of 2050 ppb.

\subsection{Discussion}

The data presented can be considered as one of the first steps to understanding the sources and problem of mer- cury contamination in the Ankobra River Basin. Water exhibited much lower $\mathrm{Hg}$ concentrations than tailings and sediments. $\mathrm{Hg}$ concentration in water from many streams far exceeded the World Health Organization (WHO) maximum guide limit of $1.0 \mathrm{ppb}$ [14]. These elevated mercury concentrations occur in streams in areas with intense small-scale mining activity and from streams carrying drainage from the old tailings dumps with high Hg levels. The most pervasive contamination of $\mathrm{Hg}$ in stream waters generally come from the Ankobra River and a mosaic of tributaries around the Bogoso area where artisanal mining activities are most profound, par- ticularly around the village of Dumasi and its satellite communities (Figure 2). However, the single highest mercury concentration in water came from a stream draining old tailings dumps at Bondaye with elevated mercury levels.

These observations are not surprising as mercury is the chemical used in gold extraction by these traditional small miners. All samples taken from streams where these small miners operate gave high mercury values. Some of these miners amalgamate their concentrate right in the streams leading to the spilling of the $\mathrm{Hg}$ into the streams (Figure 3). In fact the low level of mercury in even stream waters with active artisanal mining activities is not surprising. Hem [15] has pointed out that mercury in water opened to the atmosphere is likely to be much lower owing to its tendency to escape via vaporization. It may also form chloride and hydroxide complexes depending on $\mathrm{pH}$ and total chloride concentration.

Sediments from streams and old tailings dumps have Hg concentrations far in excess of the maximum allowable concentration of $10 \mathrm{ppb}$ of $\mathrm{Hg}$ in these media that 
Table 3. Summary of remediation methods.

\begin{tabular}{|c|c|c|c|c|}
\hline METHOD & DESCRIPTION & ADVANTAGES & DISADVAN-TAGES & SPECIAL REQUIREMENTS \\
\hline Removal & $\begin{array}{l}\text { Dredging and pumping out } \\
\text { contaminated materials }\end{array}$ & Well-tested and effective & $\begin{array}{l}\text { Expensive, lengthy process; } \\
\text { disposal sites can leak and } \\
\text { re-release contaminant; significant } \\
\text { disturbance of the environment }\end{array}$ & $\begin{array}{l}\text { Expensive equipment; must be } \\
\text { monitored periodically and } \\
\text { followed by either treatment } \\
\text { and/or burial and containment } \\
\text { in other location }\end{array}$ \\
\hline \multirow{3}{*}{ Treatment } & Physical treatment (i.e. sorting) & $\begin{array}{l}\text { Good for large quantities } \\
\text { of sediment ( } 20-40 \\
\text { tons/hour) }\end{array}$ & $\begin{array}{l}\text { Does not work with high silt, clay } \\
\text { content soils/sediments }\end{array}$ & \multirow{3}{*}{$\begin{array}{l}\text { These methods often are best } \\
\text { applied of site in contaminated } \\
\text { medium that has been removed }\end{array}$} \\
\hline & $\begin{array}{l}\text { Thermal treatment resulting in } \\
\text { volatilization }\end{array}$ & $\begin{array}{l}\text { Mercury compounds are } \\
\text { highly volatile at low } \\
\text { temperature }\end{array}$ & $\begin{array}{l}\text { Causes more atmospheric mercury } \\
\text { pollution }\end{array}$ & \\
\hline & $\begin{array}{l}\text { Chemical treatment on site or } \\
\text { off site }\end{array}$ & $\begin{array}{l}\text { Mercury reacts with } \\
\text { other compounds and } \\
\text { can be made biologically } \\
\text { unavailable }\end{array}$ & $\begin{array}{l}\text { Adding foreign chemicals into an } \\
\text { ecosystem can be dangerous when } \\
\text { you aren't sure of the outcome }\end{array}$ & \\
\hline Immobilization & $\begin{array}{l}\text { Physical barriers placed on site } \\
\text { to contain the contaminant so it } \\
\text { can no longer spread through } \\
\text { the ecosystem }\end{array}$ & Well-tested and effective & $\begin{array}{l}\text { High cost, barriers are of } \\
\text { questionable permanence, } \\
\text { unknown unintended ecological } \\
\text { effects from the destruction of the } \\
\text { benthic ecosystem }\end{array}$ & $\begin{array}{l}\text { Barriers can be top, bottom or } \\
\text { lateral side barriers; sometimes } \\
\text { barriers can be natural and not } \\
\text { man made }\end{array}$ \\
\hline Microbial Action & $\begin{array}{l}\text { Using microbes that can } \\
\text { demethylate mercury to clean } \\
\text { contaminated mediums }\end{array}$ & $\begin{array}{l}\text { Effective in sludges, } \\
\text { wastewater and } \\
\text { controlled environments } \\
\text { like the laboratory }\end{array}$ & Not proven for on site remediation & $\begin{array}{l}\text { Forms the basis of } \\
\text { phytoremediation }\end{array}$ \\
\hline Phytoremediation & $\begin{array}{l}\text { Various techniques using plants } \\
\text { to remove mercury from the } \\
\text { environment or immobilizing it } \\
\text { within the environment; } \\
\text { methods include degradation, } \\
\text { extraction, containment or a } \\
\text { combo of all three }\end{array}$ & $\begin{array}{l}\text { Cost effective, less } \\
\text { intrusive than other } \\
\text { methods, pollution } \\
\text { captured can be recycled } \\
\text { and reused instead of } \\
\text { mining more }\end{array}$ & $\begin{array}{l}\text { Plants grow slow and results take a } \\
\text { while, mercury captured in the } \\
\text { plant may be available to wildlife } \\
\text { feeding on the plant, not well } \\
\text { tested, environment must be } \\
\text { suitable to the accumulating plant }\end{array}$ & $\begin{array}{l}\text { Best for sites with low to } \\
\text { medium levels of } \\
\text { contamination }\end{array}$ \\
\hline $\begin{array}{l}\text { Water Quality } \\
\text { Management }\end{array}$ & $\begin{array}{l}\text { Manipulating the water quality } \\
\text { such as oxygen content or pH to } \\
\text { ensure methyl mercury } \\
\text { production will not occur }\end{array}$ & $\begin{array}{l}\text { Cost effective, less } \\
\text { intrusive, not highly } \\
\text { technical }\end{array}$ & $\begin{array}{l}\text { Manipulations need to be } \\
\text { monitored, and may likely need } \\
\text { manipulation often; may disrupt } \\
\text { some ecosy funcstemtioning }\end{array}$ & $\begin{array}{l}\text { Most easily implemented by } \\
\text { current water managing } \\
\text { agencies }\end{array}$ \\
\hline
\end{tabular}

Source: (Adopted from Fuller [3]).

would require immediate remedial action [16]. Mercury concentrations in these media are about 5 to more than 500 times the maximum allowable limits. The results demonstrate that $\mathrm{Hg}$ use by artisanal miners and $\mathrm{Hg}$ in old tailings dumps of large scale mining activities constitute the two major anthropogenic sources of mercury contamination in the area.

The two extremely high anomalous Hg values in the 


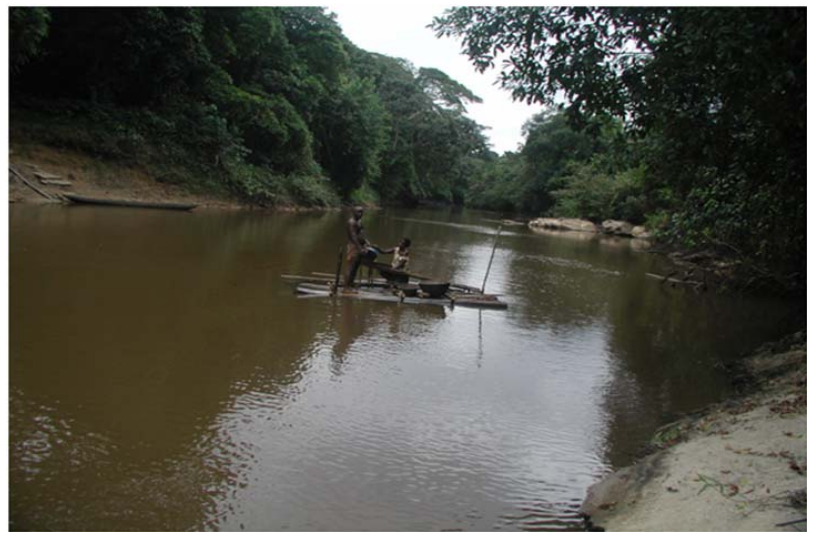

Figure 3. Artisanal miners wining gold from the bed of the Bonsa River using mercury.

Bondaye and Preseta mine ancient tailings (Area A in Figure 2) are related to historic Hg use in gold processing. From the inception of large-scale mining in the area from 1897 to the early 1990s, $\mathrm{Hg}$ was the chemical of choice for gold extraction by all commercial gold miners in the area. Small-scale miners are presently reworking the tailings dumps illegally, sending uncontrolled sediments and leachate containing $\mathrm{Hg}$ into the Ankobra and its tributaries.

\subsection{Containing Widespread Contamination in the Basin}

The relatively low level of $\mathrm{Hg}$ concentration in watercompared to concentration in sediments and mine tailings is not surprising. The results are indeed consistent with observation from studies elsewhere, where it has long been recognised that $\mathrm{Hg}$ is more efficiently transferred from water to bottom sediments [17-19]. Such rapid transfer is possibly through mechanisms such as sorption on suspended or bed load material, clay and organic material [20]. This is supported by the study of Hg speciation in bottom sediments of water reservoirs, which has shown that physically sorbed admixture is the predominant form of $\mathrm{Hg}$ occurrence in bottom sediments [17]. Such forms of Hg exhibit weak bonds and can easily be extracted from the sediments under conditions of rainstorms resulting in seasonal flushing of doses of $\mathrm{Hg}$ into water [20]. The high Hg concentrations in streambed alluvium and old mine tailings in the area constitute major sources of $\mathrm{Hg}$ contamination in surface waters. Varekam et al. [18] have pointed out that such high Hg contaminant sources present serious environmental problems as erosion of soils with high mercury loading brings these mercury bearing particles into the aquatic system.

Earlier studies have indicated augmented mercury concentrations in fish and plant species from the study area
[6]. One possible pathway for fish and plant uptake of $\mathrm{Hg}$ would be transfer from sediments through methyla- tion, which ensures a more bioavailable form of $\mathrm{Hg}$ [21]. It is also known that invertebrates that ingest large quan- tities of sediments may accumulate higher concentrations of $\mathrm{Hg}$ toxin than species that ingest leaf material [21]. The dangers posed by high mercury concentrations in sediments have equally been echoed by Hem [15] who pointed out that mercury ingested from sediments gets concentrated in the successive biological species along aquatic food chains so that fish that live in mildly contaminated environment may contain too much mercury to be used safely for food.

These mercury-laced dumps and sediments pose real threat to the general environment in the area, as these sources are capable of re-supplying mobile mercury to streams in the area during rainstorms. Currently the old tailings dumps have been evaluated to contain considerable gold resources, and ever since this disclosure, thousands of illegal small-scale miners have besieged these dumps. Their activities are sending considerable tailings into the drainage system.

There is the urgent need to put intervention measures in place to clean up the area to prevent widespread mercury contamination in the wider Ankobra basin that serves numerous communities. Any efforts to contain the contamination and possibly carry out remediation of mercury endemic sites would require careful planning. In the first place, it would require either curtailing the work of small-scale miners using mercury or providing the miners with technical support and education to use mercury retorts. However these efforts at ensuring that these miners use retorts in the past has been quite fruitless.

\subsection{Options for Remediation and Challenges}

Mercury pollution is an acclaimed human health hazard and the degree of its toxicity is dependant on its speciation. When converted to methyl mercury by bacteria in stream water and sediments, its toxicity could be augmented up to a thousand fold that of elemental mercury due to its facilitated ability to cross cell membranes and interact in biological systems [1]. Consequently, remediation of mercury contaminated sites, where they are located close or have the potential to impact watersheds, is gaining urgent priority in water quality management globally.

The impacts and extent of mercury pollution in Ghana are not fully understood. Remediation strategy for these contaminated sites would be challenging, as remediation can only be effective if there is a thorough understanding of the spatial scale of the pollution and the chemical forms of the mercury. This exploratory work has pro- 
vided useful information on the sources and scale of mercury contamination in the study area. The contaminated sites are shown in Figure 3 as A, B, C, D, and E. Sites A and $\mathrm{C}$ are ancient tailings dumps at Prestea and Tarkwa, respectively. Site B is the Ankobra River near Dumasi while sites $\mathrm{D}$ and $\mathrm{E}$ are streams being worked by small scale miners.

However, the information cannot be said to be adequate for full-scale remediation of the problem as this would require thorough understanding of the scale of pollution, the chemical forms of the mercury in the contaminated media, the range of mercury-relevant sites parameters, that usually vary from location to location due to changes in temperature, $\mathrm{pH}$, flow rate, solvent types, etc. [3].

The current levels of data is therefore limited for any full scale clean up measure, but provide the basis for further work to provide the needed information for cleaning the contaminated sites. According to the USEPA [19] six main categories of remediation techniques have been widely used-removal of the contaminated media; treatment of the medium, immobilisation of the contaminant, microbial remediation, phytoremediaiton and water quality management. The merits and demerits of each of these techniques have been summarised by Fuller [3] (Table 3).

Any strategy to decontaminate the identified sites would require an evaluation of these techniques on the basis of their potential to succeed. Since the Ankobra Basin is extensive, it will probably require multiple remediation methods at the different sites. This will probably require detailed individualised response plans that require more detailed information for the different sites in the basin. Such a remediation strategy is necessary and urgently needed to clean the Ankobra River and its tributaries and the scattered mercury-laced old tailings dumps identified in this study to prevent a pluming ecological disaster in the area.

\subsection{Securing Processing Alternatives to Mercury in the Artisanal Mining Sector}

The remediation must address mercury sinks and production pathways as the most critical targets for cleaning. In this particular study area, the challenges presented by contaminated old tailings site could be overcome once barriers are erected to prevent dispersal of material from the contaminated tailings while remediation takes place. However, it might be more challenging to address this problem with respect to areas of small scale miners, particularly, illegal miners. These migratory miners serve as constant supply of fresh mercury to streams in the area and unless their activities are curtailed, any remediation measure would be a wasteful exercise.
It is clear that efforts to stop the operations of these artisanal miners will be a fruitless venture, under current constrained opportunities for alternative sources of livelihood in the country. The other option is to examine and possibly implement alternative processing technologies other than mercury. Alternatives to mercury amalgamation such as, gravity concentration, cyanidation and froth flotation have successfully replaced mercury in the largescale mining sector. However the adoption of such technologies to the artisanal mining sector would equally be as problematic as mercury for several reasons including cost considerations and capacity constraints. Gravity concentration presents a better opportunity for success. However the nature of occurrence of the gold in typical artisanal work sites in Ghana makes the application of gravity concentration unattractive. Most of the gold is too fine and gravity concentration would not be an effec- tive technology.

These problems not withstanding, it is an important challenge for efforts to be geared towards the development of alternative processing technology for the artisanal mining sector. Until an alternative to mercury is found, any efforts any to clean up contaminated sites might only constitute a temporary solution.

\section{Conclusions and Recommendations}

The application of mercury in gold ore dressing in smallscale mining and historic application of mercury in gold extraction by large-scale miners have resulted in contamination of portions of the Ankobra Basin, including scattered mercury-laced old tailings dumps at Bondaye, Prestea and Tarkwa. These mercury contaminated tailings dumps and streambed alluvium present serious environmental challenges as these serve as reservoirs for the supply of $\mathrm{Hg}$ into water bodies through erosion. The regulatory authorities would have to discourage the direct discharge of untreated mine drainage into streams, particularly the Bonsa and Ankobra Rivers, which serve as sources of domestic water supplies for the area. Urgent measures are needed to clean up delineated mercury contamination in the area. However, this would require a more detailed study of the sites and a thorough evaluation of available remediation options and their effectiveness.

Since small-scale mining is an unavoidable livelihood activity, efforts should be made to explore the use of mercury free extraction technology in the sector.

Efforts must be made to develop alternative processing technologies to replace mercury in the artisanal mining sector.

\section{Acknowledgements}

The authors wish to express our sincere gratitude to the 
DANIDA-ENRECA Hydrogeological Project for providing the financial support for this study.

\section{REFERENCES}

[1] USEPA, "Nonpoint Source Program and Grants Guidance for Fiscal Year 1997 and Future Years," US Environmental Protection Agency, Office of Water, Washington DC, 1996.

[2] J. E. Gray, I. A. Greaves, D. M. Bustos and D. P. Krabbenhoft, "Mercury and Methyl Mercury Content in Minewaste Calcine, Water, and Sediments Collected from the Palawan Quicksilver Mine, Philippines,” Environmental Geology, Vol. 43, No. 3, 2003, pp. 298-307.

[3] A. Fuller, "Addressing the Environmental Mercury Problem in Watersheds: Remediation in the Guadalupe River Watershed, SAN Jose, California," Mercury Study: Report to Congress, EPA Report 452/-97-0003, 2003. http:/www.epa.gov/govttnuatwi/112nmerc/mercury.htm

[4] G. O. Kesse, "Mineral and Rock resources of Ghana," A. A. Balkema Publishers, Accord, 1985, pp. 338-339.

[5] T. M. Akabzaa, B. Banoeng-Yakubo and J. S. Seyire, "Evaluation of the status of Heavy Metal and Metalloid in Selected Mining Communities, in Adansi West and Amansie East Districts of Ashanti, Ghana," Ghana Science Journal, 2003, in press.

[6] M. Babut, R. Sekyi, A. Rambaud, M. Potrin-Gautier, S. Tellier, W. Bannerman and C. Beinhoff, "Improving the Environmental Management of Scale-Scale Mining Gold Mining in Ghana: A Case Study of Dumasi,” Journal of Cleaner Production, Vol. 11, No. 2, 2003, pp. 215-221. doi:10.1016/S0959-6526(02)00042-2

[7] E. A. Ofosu-Mensah, "Gold Mining and the Socio-Economic Development of Obuasi in Adanse," African Journal of History and Culture, Vol. 3, No. 4, 2011, pp. 5464.

[8] K. A. Dickson and G. Benneh, "A New Geography of Ghana,” Longman, London, 1988.

[9] R. G. Eppinger, P. H. Briggs, D. Rosenkrans and V. Ballestrazze, "Environmental Geochemical Studies of Selected Mineral Deposits in Wrangell—St. Elias National Park and Preserve, Alaska," USGS Professional Paper 1619, Gray and Sanzolone, 1996, p. 41.

[10] APHA, AWWA and WEF, "Standard Methods for the
Examination of Water and Wastewater," 20th Edition, Washington DC, New York, 1998.

[11] N. S. Bloom and W. F. Fitzgerald, "Determination of Volatile Mercury Species at the Picogram Level by LowTemperature Gas Spectrometry,” Analycal Chimica Acta, Vol. 208, 1998, pp. 151-161. doi:10.1016/S0003-2670(00)80743-6

[12] M. Barcelona, J. P. Gibbs, J. A. Helfrich and E. E. Garske, "Practical Guide for Groundwater Sampling," Illinois State Water Survey IDWS Contract Report 374, 1985.

[13] C. A. J. Appelo and D. Postma, "Geochemistry, Groundwater and Pollution,” 2nd Edition, A. A. Balkema Publishers, Accord, 2005.

[14] W. H. O., "Guidelines for Drinking Water Quality, Health Criteria and Supporting Information,” Vol. 2, World Health Organisation Geneva, 1996.

[15] J. D. Hem, "Study and Interpretation of the Chemical Characteristics of Natural Water," US Geological Survey Water Supply Paper, 1985, pp. 142-143.

[16] African Development Bank, "Environmental Guidelines for Mining Projects,” 1994, p. 82.

[17] P. V. Koval, G. V. Kalmychkov, V. F. Gelety, G. A. Leonova, V. I. Medvedev and L. D. Andrulaitis, "Correlation of Natural and Technogenic Mercury Sources in the Baikal Polygon, Russia,” Journal of Geochemical Exploration, Vol. 66, No. 1-2, 1999, pp. 277-289. doi:10.1016/S0375-6742(99)00041-2

[18] J. C. Varekam, B. Kreulen, B. Brink and E. L. Mecray, "Mercury Contamination Chronologies from Conecticut Wetlands and Long Island Sound Sediments," Environmental Geology, Vol. 43, 2003, pp. 268-282.

[19] United States Environmental Protection Agency, USEPA, "Mercury Study Report to Congress, Volume II: An Inventory of Anthropogenic Mercury Emissions in the United States.” Investigation Number EPA-452/R-97-004, 1997.

[20] E. A. Jenne, "Adsorption of Metals by Geomedia: Variables, Mechanisms and Model Application,” Academia Press, Boston, 1997.

[21] M. G. Kelly, "Effects of Heavy Metal in the Aquatic Biota. In the Environmental Geochemistry of Mineral Deposits. Part A: Processes, Techniques and Health Issues," In: S. G. Plumlee and J. M. Logsdon, Eds., Reviews in Economic Geology, Vol. 6A, 1999, pp. 363-371. 